\title{
SPECIFIC CIRCULATING IMMUNE COMPLEXES IN ACUTE CHAGAS' DISEASE
}

\author{
Ricardo CORRAL, Héctor FREILIJ \& Saúl GRINSTEIN
}

\section{S U M M A R Y}

The presence of circulating immune complexes formed by IgM and IgG (CIC-IgM and CIC-IgG) was investigated, using antigen-specific enzyme-immunoassays (ELISA), in 30 patients 'with acute Chagas' disease who showed parasitemia and inoculation chagoma. Control population consisted of patients with chronic T. cruzi infection (30), acute toxoplasmosis 10), leishmaniasis (8), rheumatoid arthritis (3) and healthy individuals with negative serology for Chagas' disease (30). Acute chagasic patients were 100\% CIC-IgG and 96.66\% CIC-IgM positive whereas immunofluorescence tests yielded $90 \%$ and $86.66 \%$ of positivity for specific IgG and IgM antibodies, respectively. Chronic patients were $68 \%$ CIC-IgG and $0 \%$ CIC-IgM positive. The 30 negative and the 21 cross-reaction controls proved negative for ELISA (CIC-IgM and CIC-IgG). The high sensitivity of ELISA assays would allow early immunologic diagnosis, as well as prompt treatment, of acute $\mathbf{T}$. cruzi infection, thus eliminating the problem of the false-positive and false-negative results which affects traditional methods for detection of circulating antibodies.

KEY WORDS: Acute Chagas' disease; Circulating immune complexes; ELISA.

\section{N T ROD U G TIO N}

Chagas' disease or American trypanoso. miasis, whose etiologic agent is Trypanosoma cruzi, is one of the major health problems in many areas of Latin America (MILES ${ }^{24}$ ). Diagnosis of human T. cruzi infection still offers difficulties, both for parasite and antibody determination. Detection of specific immunoglobulin M. (IgM) antibodies is useful for the difficulties, both for parasite and antibody desites (DESMONTS et al. ${ }^{12}$; CAMARGO \& AMATO NETO 4). However, anti-T. cruzi immuno. globulins are not found in this fraction in all cases of human acute Chagas' disease. Either false-positive or false-negative reactivity is 11kely, as has already been communicated for this protozoan infection (SCFMUNIS et al. 29 ): The development of new techniques to impro- ve the immuno-diagnosis of this parasitosis, as recommended by the World Health Organization (WHO ${ }^{33}$ ), would therefore be a great step. forward.

The presence of antibody-bound antigens has been described in bacterial, viral and pa. rasitic diseases (MOHAMMED et al. 25 ; STAGNO et al. ${ }^{30}$; LAMBERT et al. ${ }^{19}$ ). Circulating immune complexes (CIC) have been demonstrated in serum from both animals and individuals. infected with T. cruxi (CHAVES et al. 6; MARCIPAR et al, 22). CIC formed by IgM (CIC-IgM) have been identified in chagasic patients during the acute stage, by precipitation with po. lyethyleneglycol and double diffusion (MARTIN et al. ${ }^{23}$ ). We have recently reported de.

Hospital de Niños "Ricardo Gutierrez"; Laboratorio de Virologia; Gallo 1330, (1425) Buenos Aires, Argentina. R.C. is a fellow of C.I.C. (Comisión de Investigaciones Cientfficas de la Provincia de Buenos Aires, Argentina). 
CORRAL, R.; FREILIJ, H. \& GRINSTEIN, S. - Specific circulating immune complexes in acute Chagas' disease. Rev.

Inst. Med. tro, São Paulo, 29(1):26-32, 1987.

tection, by enzyme-linked immunosorbent assay (ELISA), of CIC formed by immunoglobulin G (CIC-IgG) in patients of different ages with acute and chronic Chagas' disease (KAFN et al. ${ }^{18}$ ). We present here the results obtained using this technique to detect CIC-IgM during the acute stage of human $T$. cruzi infection.

\section{MATERIAL AND METHODS}

T. cruzi antigen: it was prepared from the RA strain of T. cruzi (GONZALEZ CAPPA et al. ${ }^{15}$ ). The epimastigotes were cultured in a bloodless biphasic medium. The liquid phase contained brain heart infusion broth (Difco Laboratories, Detroit, Mich.) $28 \mathrm{~g}$, glucose $10 \mathrm{~g}$, liver extract (Difco) $10 \mathrm{~g}$ and distilled water 1,000 ml. The solid phase consisted of brain heart infusion broth (Difco) $38 \mathrm{~g}$ and agar (Difco) $20 \mathrm{~g}$. Epimastigotes 'were harvested, washed three times and centrifuged at $10,000 \mathrm{x} \mathrm{g}$ for $60 \mathrm{~min}$ at $4^{\circ} \mathrm{C}$. Soluble extracts of the packed organisms were prepared by lysis with distilled water, freezing and thawing 10 times and so. nicated by subjecting them to two 30 sec pulses at 50 watts in an ice bath using a Sonifier Cell Disruptor W 185 (Heat Systems-Ultrasonics, Inc., N.Y.). This RA antigen yielded 3.4 $\mathrm{mg}$ of protein per $\mathrm{ml}$, as determined by the LOWRY et al. ${ }^{21}$ method with bovine serum albumin as the standard.

Anti-T. cruzi antiserum: it was obtained from two $2,500-3,000 \mathrm{~g}$ young male rabbits inoculated by intramuscular route with $7.5 \times 10^{6}$ blood. stream RA strain parasites, purified from Rockland mice at the peak of parasitemia (seven days post-infection). The rabbits were bled 20 days after receiving parasites and the sera were inactivated for $30 \mathrm{~min}$ at $56^{\circ} \mathrm{C}$. The immunoglobulin fraction was separated by preci. pitation with ammonium sulfate (Sigma Chemical Co., St. Louis, Mo.), $33 \%$ of saturation (HERBERT et al. ${ }^{16}$ ), and purified by immunoadsorption (AVRAMEAS \& TERNYNCK ${ }^{3}$ ) using RA antigen (see above). The rabbit antiT. cruzi immunoglobulins used to coat the ELISA plates were also absorbed with packed guinea pig red blood cells (COSSIO et al. ${ }^{8}$ ) to rule out the possibility of antibodies in this preparation directed against any tissue antigens present in the studied sera, liable to ren. der false-positive results. The antiserum was centrifuged, filtered through a $0.45 \mu \mathrm{m}$ pore membrane (Millipore Corp., Bedford, Mass.) and stored at $-20^{\circ} \mathrm{C}$ until used. Specific antibodies against $\mathbf{T}$. cruzi were demonstrated in this preparation by indirect hemoagglutination test (titre $\supseteq 1: 512$ ).

Serologic tests: the direct agglutination (DA) (VATTUONE \& YANOVSKY 31 ), the indirect hemoagglutination (IHA) (CERISOLA et al.5) and the indirect immunofluorescence (IIF) ALVAREZ et al.1) tests (Laboratorios Polychaco, Buenos Aires, Argentina), using anti-human IgG and IgM antisera (Institute Pasteur, France), were performed by standard procedures.

Rheumatoid fator: all ELISA CIC-IgM positive sera were tested for the presene of rheumatoid fator by means of a latex slide agglutination test (Rapi-Tex RF kit, Behring Diag. nostics, American Hoechst Corp., Somerville, N.J.). Tested sera were diluted $1: 20$ in test buffer, and one drop was mixed with one drop of latex reagent on a slide, which was rocked for two min and examined visually for agglutination.

ELISA for CIC detection: microtitre polystyrene plates (Immulon 2, Dynatech Laboratories, Alexandria, Va.) with 96 flat.bottomed wells were coated with $200 \mu 1$ of rabbit anti-T. cruzi immunoglobulin diluted in $0.1 \mathrm{M}$ carbonate buffer, $\mathrm{pH}$ 9.6, and incubated overnight at $4^{\circ} \mathrm{C}$. The optimal concentration of antiserum used for coating the wells was $300 \mu \mathrm{g}$ of total protein per $\mathrm{ml}$. The plates were washed three times in phosphate buffered saline (PBS), pH 7.4 , containing $0.5 \%$ Tween 20 (Sigma). Wells were postcoated with $1 \%$ bovine serum albumin (Sigma) in PBS-Tween 20 and left at $37^{\circ} \mathrm{C}$ during $45 \mathrm{~min}$. After washing, $200 \mu \mathrm{l}$ of serum samples diluted in PBS-Tween 20 were added to each well and incubated for one hour at $37^{\circ} \mathrm{C}$. All samples were tested by duplicate. The plates were washed again and $200 \mu 1$ of conjugate, goat anti-human IgM or IgG labelled with alkaline phosphatase (Miles Laboratories, Inc., Elkhart Ind.), diluted $1: 1,000$ in PBSTween 20 were dispensed into each well. Optimal dilution of conjugate was determined as described by VOLLER et al. 32 . After $60 \mathrm{~min}$ at $37^{\circ} \mathrm{C}$ and thorough washing, $200 \mu 1$ of substrate $(0.1 \%$ p-nitrophenyl phosphate (Sigma) in diethanolamine buffer with $0.5 \mathrm{mM}$ mag- 
CORRAI, R.; FREILIJ, H. \& GRINSTEIN, S. - Specific circulating immune complexes in acute Chagas' disease. Rev.

Inst. Med. tro. São Paulo, 29(1):26-32, 1987.

nesium chloride) were added followed by 50 $\mu \mathrm{l}$ of $3 \mathrm{M}$ sodium hydroxide $30 \mathrm{~min}$ later. ELISA results were read with a Dynatech micro ELISA reader (model MR 590) at a wavelength of $410 \mathrm{~nm}$. Positive or negative values were assigned by adding two standard errors to the mean absorbance of negative control samples. All readings were made against a blank row of wells receiving the above treatment, except that human serum was replaced by PBSTween 20. Positive controls were prepared by mixing a fixed concentration $(2.2 \mathrm{mg} / \mathrm{ml}$ of purified anti.T. cruzi human IgG or IgM antibodies (FILICE et al. ${ }^{13}$ ) with different dilutions of RA antigen (originally $3.4 \mathrm{mg} / \mathrm{ml}$ ), thus obtaining immune complexes (IC) of varying antigen-antibody ratio (PERNICE \& SEDLACEXK ${ }^{26}$ ). Artificially prepared IC were mixed with $0.5 \mathrm{ml}$ of normal human serum and tested by ELISA. These controls were used in dilutions ranging from 1:100 to $1: 12,800$ in PBSTween 20. In addition, the same procedure was repeated using purified IgM or IgG from nonchagasic patients in replacement of anti-T. cruzi antibodies.

Human patient: serum samples were collected from 30 patients aged six months to 65 years with acute Chagas' disease, living in the central and northeastern Argentina, a well-known endemic area. All of them showed parasitemia, directly detectable by microhematocrit procedure (FREILIJ et al. ${ }^{14}$ ), and inoculating chagoma, a portal of entry sign characterized by painless unilateral edema of the eyelids (WHO ${ }^{33}$ ). Samples were obtained between seven and 18 days after the appearance of clinical manifestations, and were filtered through a $0.45 \mu \mathrm{m}$ pore membrane (Millipore) before stored at $-20^{\circ} \mathrm{C}$ until used. The control population, living in the same endemic area, consisted of: 15 adult and 15 pediatric cronic patients with positive serology for Chagas' disease (titres $\supseteq 1: 64$ by DA and IHA tests); 18 children, 10 with acute toxoplasmosis and 8 with cutaneous (five) or visceral (three) leishmaniasis; three patients with rheumatoid arthritis (pasitive for rheumatoid factor) and 30 healthy in. dividuals, none of them with detectable antibodies against T. cruzi (titres $<1: 8$ by DA and IHA tests).

\section{RESULTS}

Characterization of the assay: results of a representative experiment performed to characterize the sensitivity of the ELISA tests for CIC detection are shown in Fig. 1. In three separate trials, the test was able to detect artificially prepared IC at different dilutions ranging from 1:100 o 1:3,200. Higher dilutions yielded values of absorbance below the cutoff level of the assay. Negative ELISA results were obtained for IC prepared with non-specific IgM between dilutions $1: 400$ and 1:12,800; low di. Iutions $(1: 100,1: 200)$ gave absorbance readings slightly above the cutoff value. Similar results were observed for artificially prepared IC formed by IgG. Sera from five acute and five chronic chagasic patients were titrated out to confirm that the dilution chosen for ELISA tests (1:400 for CIC-IgC and 1:800 for CIC.IgM) lay on the descending linear portion of the dilution curve, in order to standardize comparison. The assay specificity was evaluated using ELISA plates coated with normal rabbit IgG in replacement of anti-T. cruzi antibodies. Consistently negative results were observed with both specific and non specific artificially prepared IC at working dilutions.

Results of ELISA in sera: results for ELISA (CIC-IgM and CIC-IgG) and IIF (IgM and IgG) are shown in Table $I$. Out of 30 acute chagasic patients, $29(96.66 \%)$ were CIC-IgM and $30(100 \%)$ CIC-IgG positive, whereas $27(90 \%)$ were IIF-IgG and $26(86.66 \%)$ IIF-IgM positi. ve (titres $\supseteq 1: 16$ ). None of the CIC IgM positive sera were positive for rheumatoid factor. Positive CIC samples had net absorbance values exceeding the mean absorbance plus twice the standard control sera error (Fig. 2). Subsequent tests showed assay sensitivity was not compromised by the arbitrary cutoff value cho. sen. The 15 aduit and the 15 pediatric patients with chronic Chagas' disease were 68\% CICIgG and $0 \%$ CIC-IgM positive (data not shown). The 30 negative and the 21 cross-reaction controls were negative for ELISA (CIC-IgG and CIC.IgM) showing the test was highly specific

\section{DISCUSSION}

Circulating immune complexes formed by specific IgM and IgG antibodies were demons- 
CORRAL, R.; FREILIJ, H. \& GRINSTEIN, S. - Specific circulating immune complexes in acute Chagas' disease. Rev. Inst. Med. . . tro. . São Paulo, $\cdots 29(1): 26-32, \cdots 1987$.

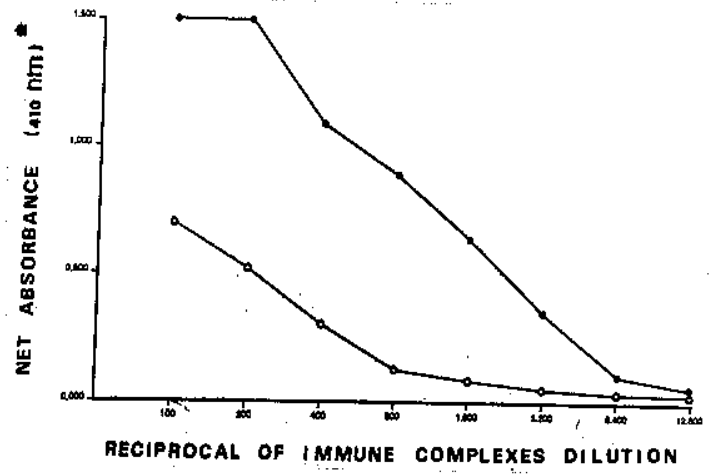

Fig. 1 - ELISA titration curve for artificially prepareu immune complexes (IC)

$\bullet-$ IC formed by anti-T. cruzi immunoglobulin $M$ antibodies and $\mathrm{RA}$ antigen diluted 1:10

$O$ IC formed by non-specific immunoglobulin $M$ antibodíes and RA antigen diluted 1:10

$(*)$ Net absorbance was determined by subtracting the mean absorbance reading on a blank row of wells from that detected on each IC dilution.

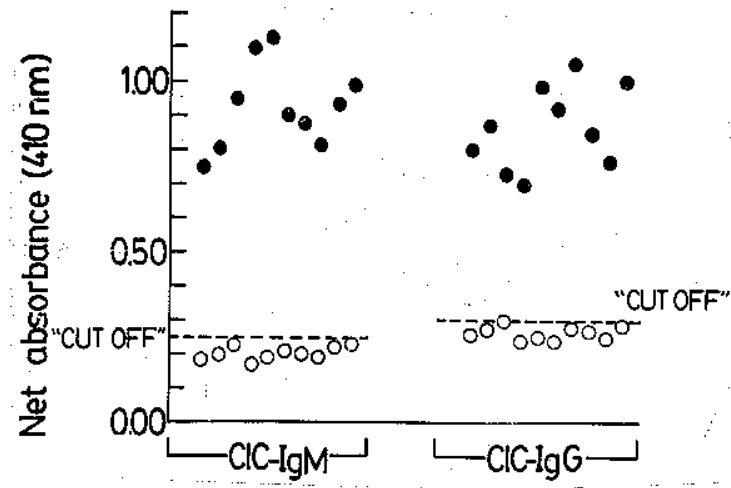

Fig. 2 - Distribution of ELISA-CIC values (net absorbance at $410 \mathrm{~nm}$ ) in sera from ten patients with acute $T$. cruzi infection ( $\bullet)$ and ten non-chagasic controls $(O)$.

trated in serum from acute T. cruzi-infected pa. tients by using an ELISA test developed in our laboratory. This method was capable of detecting artificially prepared IC from $1: 100$ through 1:3,200 dilutions. As low dilutions tended to give results of doubtful significance over the cutoff level and led to problems with non-specific reactions, they were discarded. Dilutions 1:400 for CIC-IgG and 1:800 for CIC-IgM were chosen to perform ELISA tests for pro. viding the best differences in absorbance read. ings between specific and non-specific IC.

Anti-T. cruzi IgM antibodies could not be found in four of our patients with acute Chagas' disease. Several causes of either false-positive or false-negative reactivity in specific
T A B L E I

Comparison between ELISA (CIC-IgM and CIC-IgG)* and IIF (IgM and IgG)** on sera from 30 patients with acute T. cruzi infection

\begin{tabular}{|c|c|c|c|c|c|}
\hline \multirow{2}{*}{$\begin{array}{c}\text { Patient } \\
\text { N.० }\end{array}$} & \multirow[t]{2}{*}{ Age } & \multicolumn{2}{|c|}{ Antibody titre } & \multicolumn{2}{|c|}{ ELISA } \\
\hline & & IIF-IgM & IIF-IgG & CIC-IgM & CIC-IgC \\
\hline 1 & 6 months & 1:16 & $1: 128$ & + & + \\
\hline 2 & 7 months & $1: 16$ & 1:128 & + & + \\
\hline 3 & 8 months & $1: 16$ & I:64 & + & + \\
\hline 4 & 8 months & $1: 32$ & 1:64 & + & + \\
\hline 5 & 10 months & 1:16 & 1:64 & + & + \\
\hline 6 & 11 months & 1:16 & $1: 128$ & + & + \\
\hline 7 & I year & $<1: 16$ & $<1: 16$ & - & + \\
\hline 8 & 1 year & 1:16 & 1:128 & + & + \\
\hline 9 & 1 year & 1:16 & $1: 64$ & + & + \\
\hline 10 & 2 years & $1: 32$ & $1: 256$ & + & + \\
\hline 11 & 2 years & $1: 16$ & 1:32 & + & + \\
\hline 12 & 3 years & $<1: 16$ & $<1: 16$ & + & + \\
\hline 13 & 4 years & $1: 256$ & $1: 1024$ & + & + \\
\hline 14 & 4 years & 1:16 & $1: 32$ & + & + \\
\hline 15 & 5 years & $1: 16$ & 1:64 & + & + \\
\hline 16 & 7 years & 1:16 & 1:64 & + & + \\
\hline 17 & 10 years & 1:32 & $1: 64$ & + & + \\
\hline 18 & 10 years & $1: 16$ & I:32 & + & + \\
\hline 19 & 1I years & $1: 256$ & $1: 256$ & + & + \\
\hline 20 & 12 years & $1: 16$ & $1: 128$ & + & + \\
\hline 21 & 13 years & $<1: 16$ & $<1: 16$ & + & + \\
\hline 22 & 13 years & $1 ; 16$ & $1: 128$ & + & + \\
\hline 23 & 15 years & 1:16 & $1: 64$ & + & + \\
\hline 24 & 18 years & 1:64 & $1: 256$ & + & + \\
\hline 25 & 22 years & $1: 16$ & 1:32 & + & + \\
\hline 26 & 26 years & $<1: 16$ & $1: 16$ & + & + \\
\hline 27 & 26 years & $1: 32$ & 1:64 & + & $<$ \\
\hline 28 & 32 years & $1: 32$ & $1: 128$ & + & + \\
\hline 29 & 44 years & 1:16 & $1: 32$ & + & + \\
\hline 30 & 65 years & $1: 16$ & $1: 64$ & + & + \\
\hline
\end{tabular}

* Enzyme-linked immunosorbent assay for detection of specific circulating immune complexes formed by immunoglobulin $M$ and immunoglobulin $G$, respectively.

** Indirect immunofluorescence test for specific immuno. globulin $\mathbf{M}$ and immunoglobulin $\mathbf{G}$ antibodies, respectively.

IgM detection have been described; for example, rheumatoid factor (HYDE et al,17), immusuppresion (F'REILIJ, unpublished), sera collect. ed a relatively short time after infection and competition by IgG excess (PYNDIAH et al. ${ }^{27}$ ). The formation of CIC-IgM may be another reason for the lack of positivity of IgF-IgM in certain cases during the early acute phase of Chagas' disease. In our series, only $86.66 \%$ were IIF-IgM positive and all but one presented CIC-IgM. The reason for this single negative ELISA result is not clear. Specific IgM could not be detected by standard methods (IIF, ELISA, solid-phase IgM assay, DA with and without 2-mercaptoethanol) at different centres, and no follow-up was available for this 
CORRAL, R.; FREILIJ, H. \& GRINSTEIN, S. - Specific circulating immune complexes in acute Chagas' disease. Rev. Inst. Med. tro. São PauIo, 29(1):26-32, 1987.

patient. All acute patients were CIC-IgG positive, as well as $68 \%$ of chronic cases, indicating that CIC-IgG are present not only during the acute phase of Chagas' disease. CIC-IgM were not found in chronic chagasic patients and may be considered as immunologic markers of acute $\mathbf{T}$. cruzi infection.

Out of our 30 acute patients, three (cases N. 7, 12 and 21) exhibited no detectable antither by IIF nor by DA and IHA performed at different laboratories (data not shown). Two other patients not included in our work behaved likewise. One of them, studied during 1979, had a congenital immuno suppressive disease with a history of periodic blood transfusions He underwent surgery because of an endocraneal hypertensive syndrome compatible with a tumoral mass, and amastigote nests were seen at histology. The other case, a congenitally infected newborn from Chaco, Argentina, reported by DE STORNI et al.11, had unremitt. ing severe parasitemia. Neither of them presented detectable antibodies to T. cruzi for at least six months post-infection. One of our acute patients (case N. 26) had negative IIF IgM and low IIF-IgG antibody titres. When heterogeneous populations are studied, considerable individual variation can be observed. Therefore, negative IgM antibody results at an early stage of the disease must be considered with caution (COSSIO et al. ${ }^{9}$ ).

MARTIN et al. ${ }^{23}$ have demonstrated, by precipitation with polyethyleneglycol and dooble diffusion, that IgM is the main immonoglobulin in CIC from acute $\mathbf{T}$. cruzi-infected patients, particularly in the first 15 days of clinical evolution. The results obtained by the se investigators using Clq binding test show only $70 \%$ of acute CIC positive patients. Therefore, the ELISA assays seem more suitable, as they are simpler to perform, show nigher sensitivity and require no radioactive material.

However, several problems remain unsolved before the true potential of these new serologic markers can be fully evaluated. To start with, as far as specificity is concerned, crossreaction controls where CIC were negative could only rule out toxoplasmosis and leishmaniasis. T. rangeli, T. brucei or P. falciparum, though not endemic in our area (D'ALES.
SANDRO \& DEL PRADO ${ }^{10}$ ), should also be studied for cross-reacting with T. cruzi in these tests. Sera from three patients with rheumatoid arthritis (positive for rheumatoid factor) factor) did not interfere in the test. Furthermore, it is notworthy that although the absorbance values are quantitatively measured, the tests must be only considered as quantitative because they depend on many uncertain fac. tors, such as the number of free antigenic sites available for the first (plate-bound) antibody combined with the antigen.

The release of antigens by trypanosomes is or the number and class of immunoglobulins one possible mechanism by which the parasites could evade the host's immune response. T. cruzi antigens, continuously or intermittently re. leased into circulation, bind to and inactivate specific antibodies, lowering the immune response (KAHN et al. ${ }^{18}$ ). Thus, trypanosomes could escape from the active humoral and celIular response, thereby persisting in the bloodstream, ARAUJO et al. 2).

The possible pathogenic role of CIC in Chagas' disease remains unclear. CIC were found deposited in animal tissues resulting in tissue damage upon further reaction with plasma factors and cells through hypersensitivity phenomena. "In vivo" formation of CIC, particularly those formed in antibody excess, may activate the complement system and increase vascular permeability (CHAVES et al. ${ }^{7}$ ). This latter outcome could also be related to the appearance of edema, a clinical manifestation detection of the whole parasite (e.g. xenodiagobserved in the acute stage of $\mathbf{T}$. cruxi infection RASSI 28). However, the presence in serum of IC is not necessarily accompanied by a pathologio process (LAMBERT et al. ${ }^{20}$ ).

The development of specific, sensitive and reliable techniques to demonstrate the known presence of free and antibody-bound circulating parasite antigens in American trypanoso. miasis (MARCIPAR et al. 22; KAHN et al. ${ }^{18}$; ARAUJO et al. ${ }^{2}$ ), is an important step towards improving diagnosis and a better understanding of the natural evolution of this complex disease. While antibody serology merely provides an indirect proof of infection, our ELISA tests for CIC detection allow the immunologic 
CORRAL, R.; FREILIJ, H. \& GRINSTEIN, S. - Specifto circulating immune complexes in acute Chagas' disease. Rev.

Inst. Med. tro. São Paulo, 29(1):26-32, 1987.

demonstration of parasite-specific antigen in the host, and could be considered akin to the classical parasitologic diagnosis based on the detection of the whole parasite (e.g. xenodiag. nosis, Strout's method, fresh blood observation).

Our results show that ELISA (CIC-IgM), together with the microhematocrit procedure for parasite concentration, may represent a po. werful combination of tests to assure the simple and inexpensive detection of acute Chagas' disease.

\section{ACKNOWLEDGEMENTS}

This work was supported by grant 3-P-810014-03 from the IDRC (International Develop. ment Research Centre), Canada.

\section{RESUMEN}

\section{Complejos inmunes circulantes específicos en pacientes con enfermedad de Chagas aguda}

Se investigó la presencia de complejos inmunes circulantes formados por IgM e IgG (CIC-IgM y CIC-IgG), utilizando enzimoinmunoensayos ELISA) antígeno-específicos, en 30 pacientes con enfermedad de Chagas aguda que presentaban parasitemia y chagoma de inoculación. La población control estaba formada por pacientes con infección crónica por T. cruzi (30), toxoplasmosis aguda (10), leishmaniasis (8), artritis reumatoidea (3) e individuos sanos con serología negativa para Chagas (30). Los pacientes chagásicos agudos fueron $100 \%$ CICIgG y $96,66 \%$ CIC-IgM positivos, mientras que las pruebas de inmunofluorescencia para anticuerpos específicos de tipo IgG e IgM mostraron $90 \%$ y $86,66 \%$ de positividad, respectivamente. Los pacientes cronicos fueron $68 \%$ CIC. IgG y 0\% CIC-IgM positivos. El resto de los controles arrojaron resultados negativos por ELISA CIC-IgM y CIC-IgG). La alta sensibilidad del ELISA permitiría un diagnóstico inmunológico temprano, como así también un tratamiento inmediato, de la infeccin aguda por T. cruzi, eliminando así el problema de resultados falsos-positivos $y$ falsos-negativos que afecta a los métodos tradicionales para detección de anticuerpos circulantes.

\section{REFERENCES}

1. ALVAREZ, M.; CERISOLA, J. \& ROHWEDDER, R. W. - Test de inmunofluorescencia para el diagnóstico de la enfermedad de Chazas. Bol. chil. Parasit., 23: 4-9, 1968.

2. ARAUJO, F. G.; CHIARI, E. \& DIAS, J. C. P. - Demonstration of Trypanosoma cruzi antigen in serum from patients with Chagas' disease. Lancet, 1: 246249, 1981.

3. AVRAMEAS, S. \& TERNYNCK, T. - The cross-linking of proteins with glutaraldehyde and its use for the preparation of immunoadsorbents. Immunochemistry, 6. 53-66, 1969.

4. CAMARGO, M. E. \& AMato NETO, V. - Anti-T. cruxi antibodies as serological evidence of recent infection. Rev. Inst. Med. trop. S. Paulo, 16: 200-202, 1974.

5. CERISOLA, J.; FATALA CHABEN, M. \& LAZARI, J. - Test de hemoaglutinación para el diagnóstico de la enfermodad de Chagas. Pren. méd. argent., 49: 1761 $1765,1967$.

6. Chaves, J.; FERRI, R. G.; KLIEMANN, T. A.; IRU LEGUI, I. \& SOUZA, H. B. W. T. - Complexos imunes circulantes na doença de Chagas experimental. Identificação de antígenos parasitários nos complexos. Rev. Inst. Med. trop. S. Paulo, 21: 77-81, 1979.

7. ChaVES, J.; MARIANO, O. N.; SOUZA, H. B. W. T.; IRULEGUI, I. \& COPPI VAZ, C. A. - Deposição de complexos imunes na doença de Chagas experimental. Rev. Inst. Med. trop. S. Paulo, 24: 11-15, 1982.

8. COSSIO, P. M.; DIEZ, C.; SZARFMAN, A.; KREUTZER, E.; CANDIOLO, B. \& ARANA, R. - Demonstration of a serum gamma globulin factor which reacts with endocardium and vascular structures. Circulation, 49: 13.21, 1974.

9. COSSIO, P. M.; RABINOVICH, A.; MAIZTEGUI, J. I.; CARBALLAL, G.; CASANOVA, M. B.; RITACCO, v. \& ARANA, R. - Immunofluorescence anti-Junin virus antibodies in Argentine hemorrhagic fever. Intervirology, 12: 26-31, 1979.

10. D'ALESSANDRO, A. \& DEL PRADO, C. E. - Search of Trypanonsoma rangeli in endemic areas of Trypsnosoma cruzi in Argentina and Brazil. Amer. J. trop. Med. Hyg., 26: 623-627, 1977.

11. DE STORNI, R.; BaKos, E.; BUSTAMANTE, A. \& VANIOFF, J. A. - Un caso de infección chagásica producida por una cepa atricica de Trypanosoma crual en un recién nacido. Medicina (B. Aires), 44: 287-291. 1984 .

12. DESMONTS, G.; NAOT, Y. \& REMINGTON, s. s. Immunoglobulin $\mathrm{M}$ - immunosorbent agglutination assay for diagnosis of infectious diseases: diagnosis of acute congenital and acquired Toxoplasms infections. J. clin. Microbiol., 14: 486-491, 1981. 
CORRAL, R.; FREILIJ, H. \& GRINSTEIN, S. - Specific circulating immune complexes in acute Chagas' disease. Rev. Inst. Med. tro. São Paulo, 29(1):26-32, 1987.

13. FILICE, G. A; YEAGER, A. S. \& REMINGTON, J. S. - Diagnostic significance of immunoglobulin $M$ antibodies to Toxoplasma gondi detected after separation of immunogloblulin $M$ from immunoglobulin $G$ antibodies. J, clin. Microbiol., 12: 336-342, 1980.

14. FREILIJ, H.; MULLER, L. \& GONZALEZ CAPPA, S. M. - Direct micromethod for diagnosis of acute and congenital Chagas' disease. J. clin. Microbiol., 18: $327-330,1983$.

15. GONZALEZ CAPPA, S. M.; BIJOVSKY, A. T.; FREILIJ, H.; MULLER, L. \& KATZIN, A. M. - Aislamiento de una cepa de Trypanosoma cruzi a predominio de formas delgadas, en Argentina. Medicina (B. Aires), 41: $118-120,1981$.

16. HERBERT, G. A.; PELHAM, P. L. \& PITTMAN, B. - Determination of the optimal ammonium sulfate concentration for the fractionation of rabbit, sheep, horse and goat antisera. Appl, Microbiol., 25: 26-36, 1973.

17. HYDE, B.; BARNETT, E. \& REMINGTÓ, J. S. Method for differentiation of non-specific from specific Toxoplasma IgM fluorescent antibodies in patients with rheumatoid factor. Proc. oc. exp. Biol. Med., 148: 1184-1189, 1975 .

18. KAHN, T.; CORRAL, R.; FREILIJ, H. \& GRINSTEIN, S. - Detection of circulating immune complexes, antigens and antibodies by enzyme-linked immunosorbent assay in human T. cruzi infection. IRCS Med. Sci., 11: $670-671,1983$.

19. LAMBERT, P. H.; BERNEY, M. \& KAZYUMBA, G. - Immune complexes in serum and cerebrospinal fluid in African trypanosomiasis. J. clin. Invest., 67: 77-85, .1981.

20. LAMBERT, P. 'H.; DIXON, F. J.; ZUBLER, R. H.; AGNELLO, V.; CAMBIASO, C.; CASALI, P.; CLARKE, J.; COWDERY, J. S.; MC DUFFIE, F. C.; HAY, F. C.; MC LENNAN, I. C. M.; MASSON, P.; MULLEREBERHARD, H. J.; PENTTINEN, K.; SMITH, M.; TAPPEINER, $G_{*} ;$ THEOFILOPOULOS, A. N. \& VERROUT, P. - A WHO collaborative study for the evaluation of eighteen methods for detecting immune complexes in serum. J. clin. Lab. Immunol., 1: 1-15, 1978.

21. LOWRY, O. H.; ROSEBROUGH, N. J.; FARR, A. L. \& RANDALL, R. J. - Protein measurement with the Folin phenol reagent. J. biol. Chem., 193: 265-275, 1951.

22. MARCIPAR, A.; BARNES, S.; LENTWOJT, E. \& BROUN, G. - Immunoenzymatic determinantion of antibody-bound soluble antigens of Trypanosoma cruzi. Appl. Biochern. iBotech., 7: 459-462, 1982.
23. MARTIN, U.; AFCHAIN, D. \& CAPRON, A. - Circlulating immune complexes in human Chagas' disease. (Presented at the 2nd. Annual Meting of Sociedad Argentina de Protozoologia. Buenos Aires, October 1982).

24. MILES, M. A. - Trypanosoma cruzi; Epidemiology In: BAKER, J. R., ed. - Perspectives in trypanoso miasis research. Chichester, Research Studies Press, 1982. p. 1-15.

25. MOHAMMED, I.; ANSELI, B. M.; HOLBOROW, E. J. \& BRYCESON, A. D. M. - Circulating immune complexes inn subacute infective endocarditis and post. streptococcal glomerulonephritis. J. clin. Path., 30: 308$311,1977$.

26. PERNICE, W. \& SEDLACEK, H. H. - Antigen-Specifio detection of soluble immune complexes by a solid. phase specific antibody system. J. immunol. Me. thods, 28: $33-40$, 1979.

27. PYNDIAH, N.; KRECH, V.; PRICE, P. \& ILHEM, J. - Simplified chromatographic separation of immunoglobulin $\mathrm{M}$ from $\mathrm{G}$ and its application to Toxoplasma indirect immunofluorescence. J. clin. Microbiol., s: 170-174, 1979.

28. RASSI, A. - Clinica: fase aguda. In: BRENER, Z. \& ANDRADE, Z., ed. - Trypanosoma cruzi e doeng de Chagas. Rio de Janeiro, Guanabara Koogan, 1979. p. 249-264.

29. SCHMUNIS, G. A.; SZARFMAN, A.; COARASA, t.; GUILLERON, C. \& PERALTA, J. M. - Anti-Trypano. soma cruxi agglutinins in acute human Chagas' disea. se. Amer. J. trop. Med. Hyg., 29: 170-178, 1980.

30. STAGNO, S.; VOLANAKIS, J. E.; REYNOLDS, D. W.; STROUD, R. \& ALFORD, C. A. - Immune complexes in congenital and natal cytomegalovirus infections of man. J. clin. Invest., 60: 838-845, 1977.

31. VATTUONE, N. H. \& YANOVSKY, J. F. - Trypanosoma cruzi: agglutination activity of enzyme-trested epimastigotes. Exp. Parasit., 30: 359-363, 1971.

32. VOLLER, A.; BIDWELL, D. \& BARTLETT, A. - Enzyme-linked immunosorbent assay. In: ROE, $\mathbb{N}$. R. \& FRIEDAN, H., ed. - Manual of clinical immunology. 2nd. ed. Washington, D. C., American Society for Mtcrobiology, 1980. p. 359-371.

33. WORLD HEALTH ORGANIZATION - Special Progtam. me for Research and Training in Tropical Diseases. Sixth programme report, 1983. p. 136-190.

Recebido para publicação em 18/2/1986. 